\title{
Editorial
}

\section{Oligometastases/Oligo-Recurrence of Lung Cancer}

\author{
Yuzuru Niibe, ${ }^{1}$ Joe Y. Chang, ${ }^{2}$ Hiroshi Onishi, ${ }^{3}$ Joseph Salama, ${ }^{4}$ \\ Takao Hiraki, ${ }^{5}$ and Hideomi Yamashita ${ }^{6}$ \\ ${ }^{1}$ Department of Radiology and Radiation Oncology, Kitasato University School of Medicine, 1-15-1 Kitasato, Minami-ku, Kanagawa, \\ Sagamihara 252-0374, Japan \\ ${ }^{2}$ Department of Radiation Oncology, Yamanashi University School of Medicine, Yamanashi, Japan \\ ${ }^{3}$ Department of Radiation Oncology, Duke University, Durham, NC, USA \\ ${ }^{4}$ Department of Radiation Oncology, Yamanashi University School of Medicine, Yamanashi, Japan \\ ${ }^{5}$ Department of Radiology, Okayama University Medical School, Okayama, Japan \\ ${ }^{6}$ Department of Radiology, The University of Tokyo Hospital, Tokyo, Japan
}

Correspondence should be addressed to Yuzuru Niibe; joe-n@hkg.odn.ne.jp

Received 2 January 2013; Accepted 2 January 2013

Copyright (C) 2013 Yuzuru Niibe et al. This is an open access article distributed under the Creative Commons Attribution License, which permits unrestricted use, distribution, and reproduction in any medium, provided the original work is properly cited.

Metastasis or recurrence of cancer has been considered as representing a near terminal life stage. As a result, for a long time, cancer patients with metastasis or recurrence have been classified as one group and treated using only systemic therapy. However, recent advances in cancer therapy have dramatically improved both local and systemic therapies. The concept of oligometastases was proposed by Hellman and Wechselbaum in 1995 [1] and revised by Niibe et al. in 2006 as oligo-recurrence [2]. These notions represent the first classification of metastasis or recurrence to identify subgroups for achieving long-term survival or even cure.

Oligometastases are defined as 1-5 distant metastases that can be treated by local therapy to achieve long-term survival or cure. The most important prognostic factor for oligometastases is the status of the primary lesion [3, 4]. Niibe et al. proposed the concept of oligo-recurrence to overcome this problem. Oligo-recurrence is thus defined as 1-5 distant metachronous metastases that can be treated by local therapy, under conditions of a controlled primary lesion. More favorable subgroups of oligometastases have subsequently been classified. Niibe et al. proposed the classification and naming of sync-oligometastases and oligo-recurrences [3]. Sync-oligometastasis indicates a state of oligometastases with active but controllable primary lesions. This classification appears reasonable.

Based on a review of the literature, we propose a more detailed classification of metastases and recurrence.
Table 1 shows the Niibe-Onishi-Chang classification, which includes not only oligometastases, but also polymetastases. Oligometastases and oligo-recurrences usually offer a better prognosis than polymetastases. However, oligometastases and oligo-recurrence are cancer- and organ-specific. The appearance status of oligometastases or oligo-recurrence is thus sometimes equivalent to polymetastases such as in pancreatic cancer, sarcoma, or malignant melanoma, although the last one is related to the abscopal effect, a key cure-related phenomenon for oligometastases and oligo-recurrences [57]. Among oligometastases and oligo-recurrences, patients with 1-2 metastases and recurrences reportedly show better prognosis than those with 3-5 metastases and recurrences [8]. In oligo-recurrence of NSCLC in only the brain or adrenal gland, patients achieve favorable survival [4, 9]. Lung or liver metastases of colon or rectal cancer are also be associated with favorable survival $[10,11]$. Patients with oligorecurrence of renal cell carcinoma also achieve long-term survival [12]. In sync-oligometastases of NSCLC affecting only the brain or adrenal gland, patients reportedly achieve relatively favorable survival $[9,13]$. In sync-oligometastases of colon and rectal cancer, renal cell cancer also reportedly shows relatively favorable survival [10-12]. In oligorecurrence of breast cancer, patients are reported to achieve relatively favorable survival $[14,15]$. Niibe et al. reported that all seven of breast cancer patients with bone-only oligorecurrence were still alive at the last followup (median 
TABLE 1: Niibe-Onishi-Chang classification.

\begin{tabular}{|c|c|c|c|}
\hline \multirow{2}{*}{ Favorable } & \multicolumn{2}{|l|}{ Intermediate } & \multirow{2}{*}{ Unfavorable } \\
\hline & Relatively favorable & Relatively unfavorable & \\
\hline \multirow[t]{2}{*}{$\begin{array}{l}\text { Oligorecurrence } \\
\text { Site no. 1-2 } \\
\text { NSCLC (brain and adrenal gland) } \\
\text { Colon and rectum cancer (lung and } \\
\text { liver) } \\
\text { Renal cell cancer }\end{array}$} & $\begin{array}{l}\text { oligo-recurrence } \\
\text { site no. 1-2 } \\
\text { breast cancer (bone, lung, and liver) } \\
\text { SCLC (brain) } \\
\text { site no. 3-5 } \\
\text { NSCLC (brain and adrenal gland) } \\
\text { colon and rectum cancer (lung and } \\
\text { liver) } \\
\text { renal cell cancer }\end{array}$ & $\begin{array}{l}\text { oligo-recurrence } \\
\text { site no. } 3-5 \\
\text { breast cancer (bone, lung, and } \\
\text { liver) } \\
\text { SCLC (brain) }\end{array}$ & $\begin{array}{l}\text { Oligometastases and } \\
\text { oligo-recurrence } \\
\text { pancreatic cancer (any site) } \\
\text { melanoma (any site) } \\
\text { sarcoma (any site) }\end{array}$ \\
\hline & $\begin{array}{l}\text { sync-oligometastases } \\
\text { site no. } 1-2 \\
\text { NSCLC (brain and adrenal gland) } \\
\text { colon and rectum cancer (lung and } \\
\text { liver) } \\
\text { renal cell cancer }\end{array}$ & $\begin{array}{l}\text { sync-oligometastases } \\
\text { site no. } 3-5 \\
\text { NSCLC (brain and adrenal } \\
\text { gland) } \\
\text { colon and rectum cancer (lung } \\
\text { and liver) } \\
\text { breast cancer (bone, lung, and } \\
\text { liver) }\end{array}$ & polymetastases \\
\hline
\end{tabular}

followup, 40 months). In sync-oligometastases of SCLC, several cases have been reported to survive more than 5 years $[16,17]$. Patients with metastatic pancreatic cancer, sarcoma, or melanoma reportedly display unfavorable outcomes [1820].

This new classification, the Niibe-Onishi-Chang classification, should be revised in the future due to the rapid improvements being achieved in local and systemic therapies for cancer. This classification is tentative, but is very important given the fact that even a decade ago, many oncologists considered patients with metastasis and recurrence in only a single group.

\section{Yuzuru Niibe Joe Y. Chang Hiroshi Onishi Joseph Salama Takao Hiraki Hideomi Yamashita}

\section{References}

[1] S. Hellman and R. R. Wechselbaum, “Oligometastases," Journal of Clinical Oncology, vol. 13, no. 1, pp. 8-10, 1995.

[2] Y. Niibe, T. Kazumoto, T. Toita et al., "Frequency and characteristics of isolated para-aortic lymph node recurrence in patients with uterine cervical carcinoma in Japan: a multi-institutional study," Gynecologic Oncology, vol. 103, no. 2, pp. 435-438, 2006.

[3] Y. Niibe, T. Nishimura, T. Inoue et al., "Oligometastases of brain only in patients with non-small cell lung cancer (NSCLC) treated with stereotactic irradiation (STI): a multi-institutional study in Japan," International Journal of Radiation Oncology, Biology, Physics, vol. 78, no. 3, p. S497.

[4] J. L. Lopez Guerra, D. Gomez, Y. Zhuang et al., "Prognostic impact of radiation therapy to the primary tumor in patients with non-small cell lung cancer and oligometastasis at diagnosis," International Journal of Radiation Oncology, Biology, Physics, vol. 84, no. 1, pp. e61-e67, 2012.
[5] M. A. Postow, M. K. Callahan, C. A. Barker et al., "Immunologic correlates of the abscopal effect in a patient with melanoma," The New England Journal of Medicine, vol. 366, no. 10, pp. 925-931, 2012.

[6] M. Takaya, Y. Niibe, S. Tsunoda et al., "Abscopal effect of radiation on toruliform para-aortic lymph node metastases of advanced uterine cervical carcinoma: a case report," Anticancer Research, vol. 27, no. 1B, pp. 499-503, 2007.

[7] K. Okuma, H. Yamashita, Y. Niibe, K. Hayakawa, and K. Nakagawa, "Abscopal effect of radiation on lung metastases of hepatocellular carcinoma: a case report," Journal of Medical Case Reports, vol. 5, article 111, 2011.

[8] J. K. Salama, S. J. Chmura, N. Mehta et al., "An initial report of a radiation dose-escalation trial in patients with one to five sites of metastatic disease," Clinical Cancer Research, vol. 14, no. 16, pp. 5255-5259, 2008.

[9] R. Holy, M. Piroth, M. Pinkawa, and M. J. Eble, "Stereotactic Body Radiation Therapy (SBRT) for treatment of adrenal gland metastases from non-small cell lung cancer," Strahlentherapie und Onkologie, vol. 187, no. 4, pp. 245-251, 2011.

[10] U. Ricardi, A. R. Filippi, A. Guarneri et al., "Stereotactic boby radiation therapy for lung metastases," Lung Cancer, vol. 75, no. 1, pp. 77-81, 2012.

[11] K. E. Rusthoven, B. D. Kavanagh, H. Cardenes et al., "Multiinstitutional phase I/II trial of stereotactic body radiation therapy for liver metastases," Journal of Clinical Oncology, vol. 27, no. 10, pp. 1572-1578, 2009.

[12] M. C. Ranck, D. W. Golden, K. S. Corbin et al., "Stereotacticbody radiotherapy for the treatment of oligometastatic renal cell carcinoma," American Journal of Clinical Oncology. In press.

[13] C. Hu, E. L. Chang, S. J. Hassenbusch III et al., "Nonsmall cell lung cancer presenting with synchronous solitary brain metastasis," Cancer, vol. 106, no. 9, pp. 1998-2004, 2006.

[14] Y. Niibe, M. Kuranami, K. Matsunaga et al., "Value of highdose radiation therapy for isolated osseous metastasis in breast cancer in terms of oligo-recurrence," Anticancer Research, vol. 28, no. 6B, pp. 3929-3931, 2008.

[15] N. Kagara, Y. Nakano, A. Watanabe et al., "Curative-intent stereotactic body radiation therapy for residual breast cancer 
liver metastasis after systemic chemotherapy," Breast Cancer. In press.

[16] Y. Niibe, K. Karasawa, and K. Hayakawa, “Ten-year disease-free survival of a small cell lung cancer patient with brain metastasis treated with chemoradiotherapy," Anticancer Research, vol. 24, no. 3B, pp. 2097-2100, 2004.

[17] R. Imai, K. Hayakawa, H. Sakurai, Y. Nakayama, N. Mitsuhashi, and H. Niibe, "Small cell lung cancer with a brain metastasis controlled for 5 years: a case report," Japanese Journal of Clinical Oncology, vol. 31, no. 3, pp. 116-118, 2001.

[18] M. Frigeri, S. De Dosso, O. Castillo-Fernandez, K. Feuerlein, H. Neuenschwander, and P. Saletti, "Chemotherapy in patients with advanced pancreatic cancer: too close ro death?" Supportive Care in Cancer, vol. 21, no. 1, pp. 157-163, 2013.

[19] W. T. van der Graaf, J. Y. Blav, S. P. Chawla et al., "Pazopanib for metastatic soft-tissue sarcoma (PALETTE): a randomized, double-blind, placebo-controlled phase 3 trial," Lancet, vol. 379, no. 9829, pp. 1879-1886, 2012.

[20] C. Mateus and C. Robert, "Major therapeutic advances in the treatment of metastatic melanoma," Bulletin du Cancer, vol. 99, no. 6, pp. 619-625, 2012. 


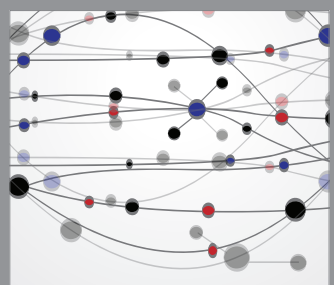

The Scientific World Journal
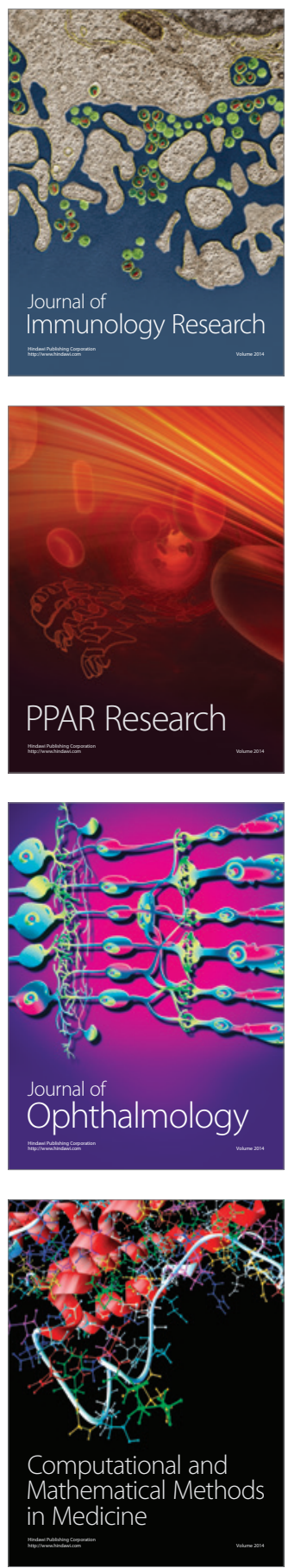

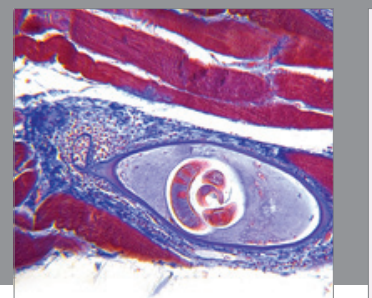

Gastroenterology

Research and Practice
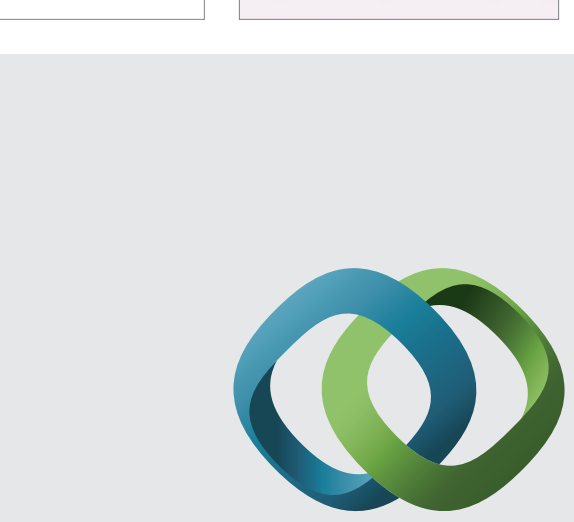

\section{Hindawi}

Submit your manuscripts at

http://www.hindawi.com
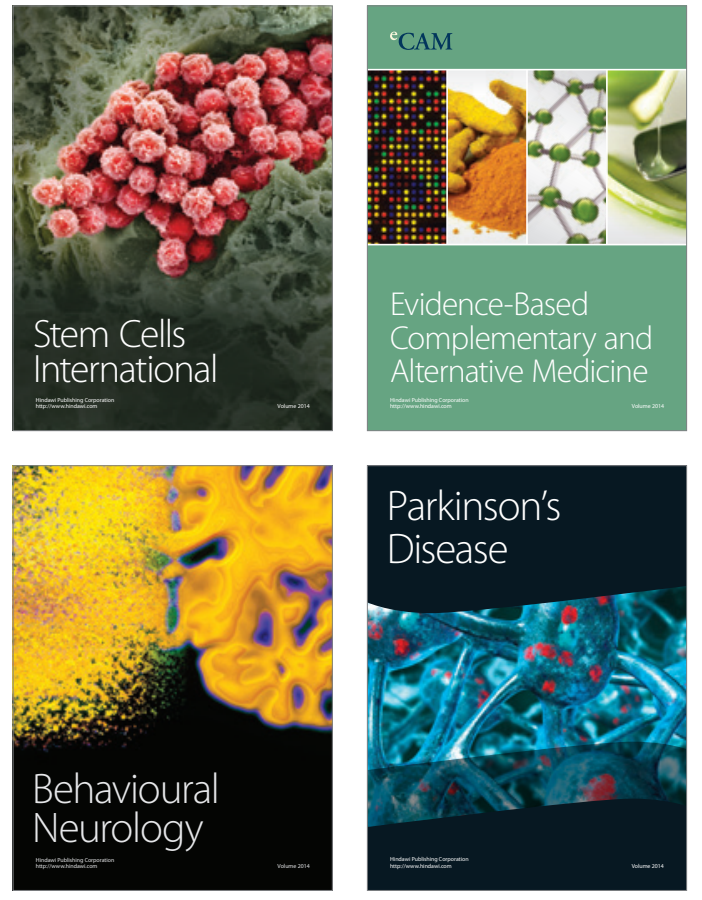
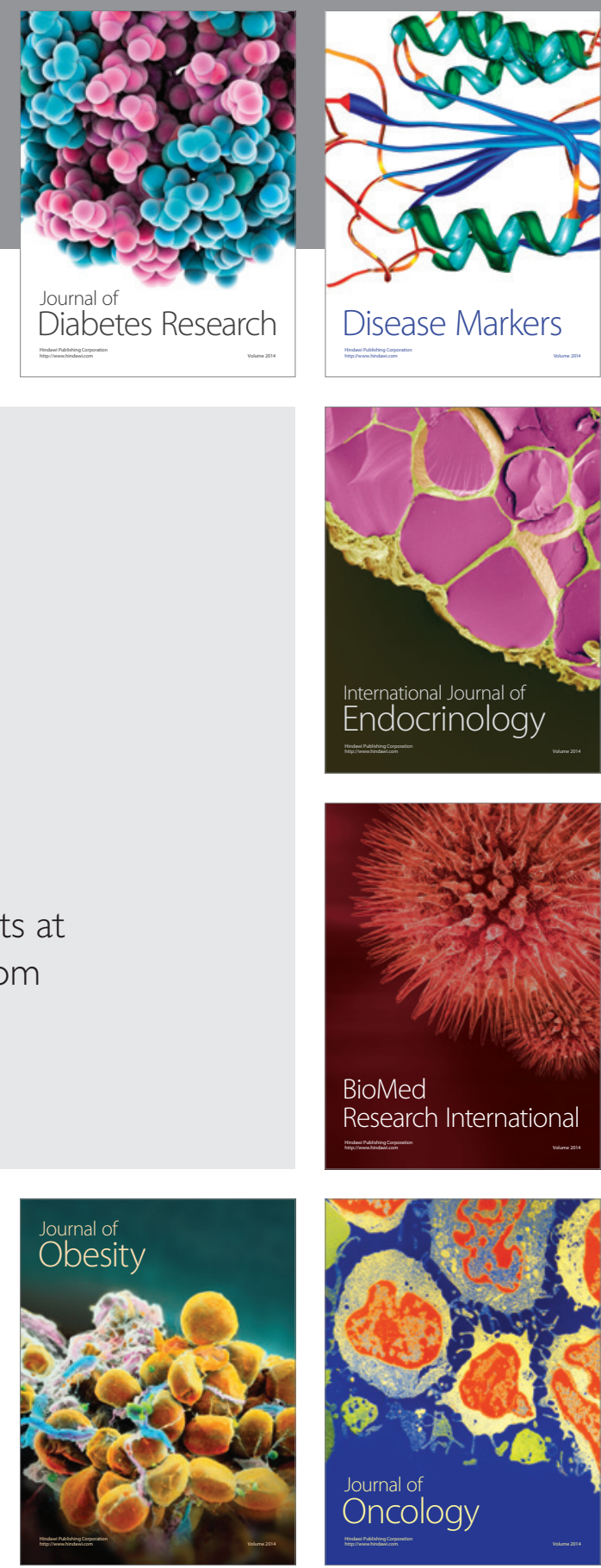

Disease Markers
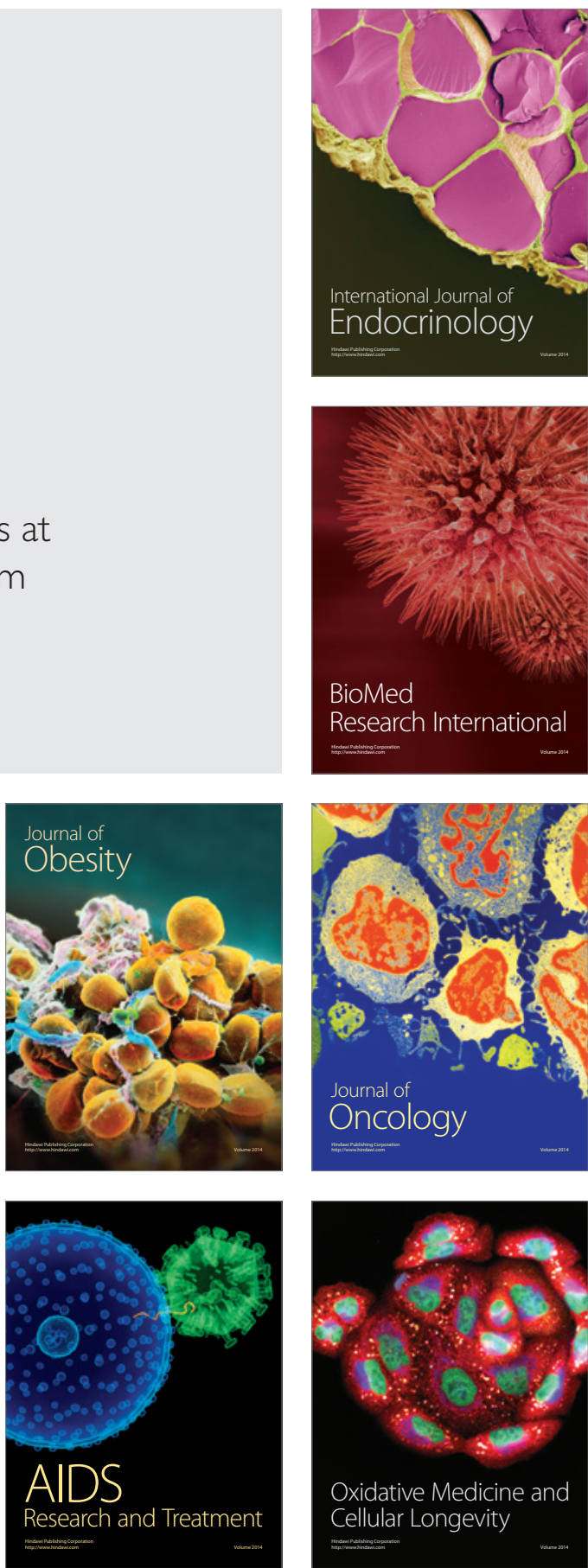